\title{
QUEEN'S
UNIVERSITY
BELFAST
}

\section{A first record of intertidal Ostrea edulis 3D structural matrices in Strangford Lough Northern Ireland - An emergent reef?}

Kregting, L. T., Hayden-Hughes, M., Millar, R. V., Joyce, P. W. S., \& Smyth, D. M. (2020). A first record of intertidal Ostrea edulis 3D structural matrices in Strangford Lough Northern Ireland - An emergent reef? Journal of Sea Research, 163, [101927]. https://doi.org/10.1016/j.seares.2020.101927

Published in:

Journal of Sea Research

Document Version:

Peer reviewed version

Queen's University Belfast - Research Portal:

Link to publication record in Queen's University Belfast Research Portal

\section{Publisher rights}

Copyright 2020 Elsevier Ltd.

This manuscript is distributed under a Creative Commons Attribution-NonCommercial-NoDerivs License

(https://creativecommons.org/licenses/by-nc-nd/4.0/), which permits distribution and reproduction for non-commercial purposes, provided the author and source are cited

\section{General rights}

Copyright for the publications made accessible via the Queen's University Belfast Research Portal is retained by the author(s) and / or other copyright owners and it is a condition of accessing these publications that users recognise and abide by the legal requirements associated with these rights.

Take down policy

The Research Portal is Queen's institutional repository that provides access to Queen's research output. Every effort has been made to ensure that content in the Research Portal does not infringe any person's rights, or applicable UK laws. If you discover content in the Research Portal that you believe breaches copyright or violates any law, please contact openaccess@qub.ac.uk. 
Authors and Address: Louise Kregting ${ }^{\mathrm{ab}}{ }^{*}$, Maria Hayden-Hughes ${ }^{c}$, Rachel V. Millar ${ }^{\mathrm{ab} 1}$, Patrick W.S. Joyce $^{\text {ab2 }}$ and David M. Smyth ${ }^{\text {bc }}$

a School of Natural and Built Environment, Queen's University Belfast, Stranmillis Road, Belfast BT9 5AG, Northern Ireland, UK

b Queen's University Marine Laboratory, Queen's University Belfast, 12-13 The Strand, Portaferry, BT22 1PF, Northern Ireland, United Kingdom

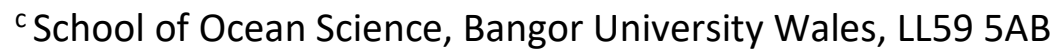

\section{* Correspondence address:}

School of Natural and Built Environment, Queen's University Belfast, Stranmillis Road, Belfast BT9 5AG, Northern Ireland, UK

E-mail: I.kregting@qub.ac.uk

\section{Present address}

${ }^{1}$ Coastal Marine Ecosystems Research Centre, Central Queensland University, Bryan Jordan Drive, Gladstone QLD 4680, Australia

${ }^{2}$ Danish Shellfish Centre, DTU Aqua, Øroddevej 80, 7900 Nykøbing Mors, Denmark 

50

Abstract

The European flat oyster Ostrea edulis once settled in high densities throughout its natural range but now exists only in small fragmented populations. In the Sea Lough of Strangford, Northern Ireland, recent increases in intertidal oyster numbers at historical sites along the north-east shore were recorded in 2018. A substantial number of conjoined oyster settlements were recorded within this density increase. One intertidal site produced numerous three-dimensional (3D) 0 . edulis specific matrices containing $>16$ oysters. In contrast, an extensive search of post and pre-1700s literature uncovered relatively few accounts of species-specific 3D 0 . edulis matrices and none relating to intertidal populations. The gregarious 3D settlements discovered during this research represent the first documented evidence of the phenomenon in Ireland. These emergent native oyster reef structures offer an insight into the possible intertidal $O$. edulis formations, which existed pre-1700 and could act as a guide to what may still be obtainable in the future.

Keywords: 3D structure; Flat oyster; Oyster; Population; Reef; Restoration. (4) 2 4 5 6 7 8 9 


\section{Introduction}

The European flat oyster, Ostrea edulis, once supported an immense inshore and offshore commercial fishery throughout its natural range from the 1600 s to the late-1800s (Yonge, 1966; Laing et al., 2006). Standing stocks during this period were substantial and by the mid-1800's the Thames Street Fish Market was selling >700 million oysters exclusively to London merchants in 1864 (Edwards, 1997). This level of exploitation could not be sustained and by the early-1900s a combination of fishing intensity, disease and anthropogenic stressors resulted in the almost total collapse of European stocks (Yonge, 1966). More than 100 years after this collapse, the native oyster remains functionally extinct at, if not totally absent from, most of its historical sites (Smyth et al., 2009; Beck et al. 2011; Lipcius et al., 2015). Consequently, numerous restoration programmes are underway to address these dwindling wild stocks (Fariñas-Franco et al. 2018; Helmer et al., 2019; Pogoda et al., 2019; https://nativeoysternetwork.org/;https://noraeurope.eu/). However, as no reference library exists relating to the biogenic feature forming capabilities of 0 . edulis, much debate persists as to what a rejuvenation might actually look like (Mieszkowska et al., 2013). Therefore, the question arises as to whether O. edulis, in a best-case scenario, would be capable of forming interconnected 3D reef structures or solitary unattached beds.

It has been presumed that $O$. edulis settles near, but independently of, its neighbours and is not a 3D reef building species (Korringa, 1951). However, this assumption has recently been challenged with the detection of mixed Crassotrea gigas and $O$. edulis subtidal reefs along the Dutch sector of the North Sea (Christianen et al., 2018). On the Bulgarian coast of the Black Sea, the discovery of large extinct subtidal $O$. edulis 3D reef structures, known as Ostrak, also contests the solitary settlement theory (Todorova et al., 2009). The Bulgarian reefs were substantial at $>7 \mathrm{~m}$ high, 30-35 m long and $10 \mathrm{~m}$ wide with matrices created entirely from 0 . edulis valves (Micu and Todorova, 2007). While local fishermen were harvesting live oysters from the Bulgarian reefs as recently as 2002, there are no living $O$. edulis on these reefs today (Todorova et al., 2009). Prior to 
these discoveries, it was questioned as to whether $O$. edulis could form 3D structures as no substantial historical evidence of live formations had been recorded (Smyth et al., 2020). However, in 1853 a report by Coste gives vague reference to the condition of fallowed 0 . edulis beds in northern France which, 'become coarse with barnacles and other parasites and adhere together in thick beds which have to be broken up' (Eyton, 1858).

If such 3D 0 . edulis reefs currently exist, they would most likely be in remote regions that once accommodated abundant wild stocks and still receive a sufficient larval supply. A location worthy of consideration as a possible site for 3D intertidal $O$. edulis structural settlements is the small, semi-enclosed sea lough of Strangford in Northern Ireland, UK. The Lough once held a historically renowned Irish stock of $O$. edulis in both the intertidal and subtidal (Day and McWilliams, 1991). In addition, Kennedy and Roberts (2006) and Smyth et al. (2020) recorded multiple O. edulis attachments of up to five oysters (known locally as 'Cloks' where traditionally fishermen said more than three joined oysters made a Clok) in remote unfished areas of the Lough.

Gregarious settlements of $O$. edulis generally require five key parameters; historical provenance of prolific oyster assemblages, a low-flush high retention hydrodynamic regimen, larval supply, suitable settlement substrate with adequate coverage and a resident fecund assemblage of adult oysters (Kennedy and Roberts, 2006). Strangford Lough meets these important criteria that would assist high density oyster settlements. Firstly, the Lough is a designated Marine Conservation Zone recognised under European legislation and considered to be in a good state of environmental health (Roberts et al., 2011). It also benefits from a zone of approximately $90 \mathrm{~km}^{2}$ which is closed to static and mobile fishing which is patrolled regularly by the authorities (Johnson et al., 2008). Furthermore, the north of Strangford Lough possesses a mean flow $<0.15 \mathrm{~m} / \mathrm{s}$, hydrodynamic conditions low enough to initiate larval pooling while also providing suitable intertidal settlement substrate (Kregting and Elsäßer, 2014; Smyth et al., 2016, 2020). Moreover, the small resident population of $O$. edulis estimated at $<800,000$ within the $75 \mathrm{~km}^{2}$ northern basin of the Lough (Smyth 
et al. 2016), could produce a substantial spawning response to high sea temperatures, such as those experienced in 2014 (MCCIP, 2017), thereby creating a situation which could be conducive to mass concentrated settlements. Therefore, it was decided to quantify the abundance of 3D structural aggregations of $O$. edulis in the intertidal zone of the Lough (Fig. 1), which may have formed 3D matrices with the potential to develop into reef formations akin to pre-1700s. This information will be invaluable for restoration and conservation management decisions.

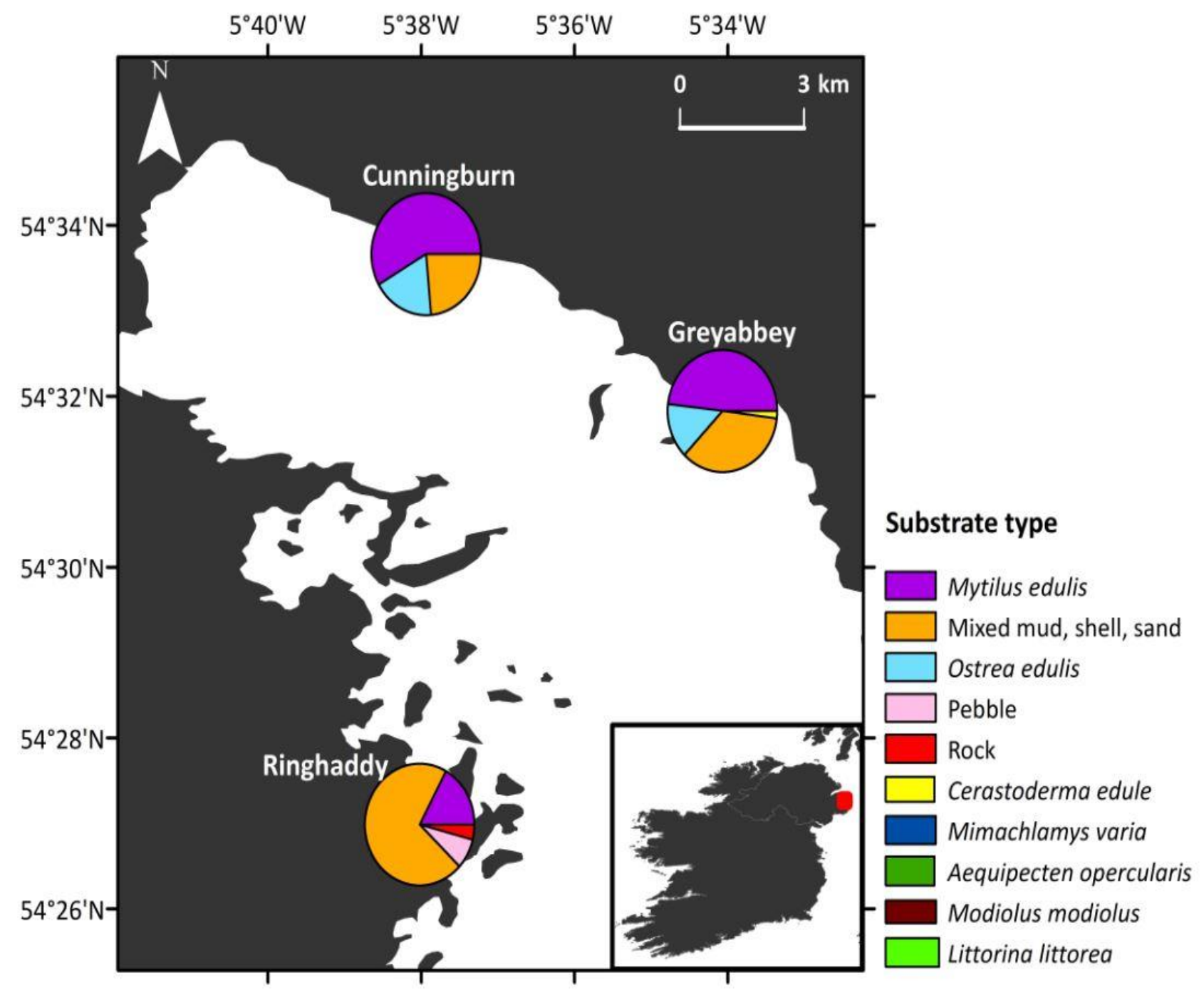

Figure 1. Historically renowned intertidal Ostrea edulis sites (Smyth et al. 2009) and associated substrate composition as per Smyth et al. (2018) in Strangford Lough, Northern Ireland, UK. 


\section{Materials and Methods}

113

\subsection{Site selection}

Historical verification of oyster sites renowned for prolific harvests in Strangford Lough were taken from the Ordnance Survey Memoirs for the Parish of Killinchy (Lewis, 1837) which identified Ringhaddy Sound, Cunningburn and Greyabbey as notable locations for "the harvesting of oysters from the high and low shore in both summer and winter" (Day and Mc Williams, 1991). Smyth et al. (2016) confirmed that the hydrodynamics and substrate type associated with the three sites would be conducive to larval retention and potential gregarious settlements. Oyster population density data was also available for all three sites from 2010-2014. It was therefore decided that the lower intertidal areas at Ringhaddy, Cunningburn and Greyabbey (Fig. 1) would be selected for investigation.

\subsection{Survey Techniques}

Surveys were undertaken during October 2010 and November 2014 and 2018 on low spring tides of $<0.5 \mathrm{~m}$ chart datum as per the 2010 protocol established by Smyth et al., (2009). A random belt transect and timed search methodology was employed at each site with sampling taking place parallel to the low water mark within three $30 \times 10$ m plots. Multiple attachments of two or more oysters were recorded both as size of individuals measured from the umbo to the ventral front edge of the shell using a Vernier caliper to the nearest $\mathrm{mm}$ and as total number attached.

\subsection{Data Analysis}

A PERMANOVA which employed a Bray-Curtis similarity matrix, with 9999 permutations was used to determine the similarities of square root transformed densities of multiple attachments/Cloks of oysters in relation to the factors site and year. Statistical analyses were carried out using PAST $3.25^{\odot}$ (Hammer et al., 2001). The age of each oyster was estimated from the size data to determine the average age for Clok assemblage. All age estimates were assigned as per Richardson et al. (1993). 


\section{Results}

Two-way PERMANOVA revealed significant differences in Clok density with regards to the factors 'Site' $\left(F_{(2,18)}=8.77, P<0.001\right)$ and 'Year' $\left(F_{(2,18)}=2.51, P<0.05\right)$ as well as a significant interaction between the factors $\left(F_{(4,18)}=4.49, P<0.001\right)$ (Table 1$)$.

Table 1. Two-way PERMANOVA summary table of Clok density per site and year.

\begin{tabular}{lccccc}
\hline Source & Sum Sq & df & Mean Sq & $F$ & $P$ \\
\hline Site & 1.39 & 2 & 0.696 & 8.77 & 0.0001 \\
Year & 0.39 & 2 & 0.199 & 2.51 & 0.028 \\
Interaction & 1.42 & 4 & 0.356 & 4.49 & 0.0001 \\
Residual & 1.42 & 18 & 0.079 & & \\
& & & & & \\
\hline
\end{tabular}

An increase in the number of Cloks was recorded at all sites in 2018 compared to previous years (Fig. 2). The greatest abundance of Cloks across all years was observed at the Cunningburn site with the greatest number recorded in 2018 (Fig. 2) where the dominant substrate was Mytilus edulis (Fig. 1). This location also contained the highest variation in the number of oysters per Clok (Fig. $2 \& 3$ ). Cunningburn site was also the only site which produced Cloks with $>4$ individuals and was unique with >10 individuals per Clok recorded for the first time in 2018. Indeed, one conjoined oyster attachment at Cunningburn had $>16$ oysters ranging from $80-120 \mathrm{~mm}$ (Fig. $3 \mathrm{~d}$ ). The remaining sites of Ringhaddy and Greyabbey did not produce multiple attached settlements in quantities which could be considered as ecosystem engineers producing 3D biogenic structures. 


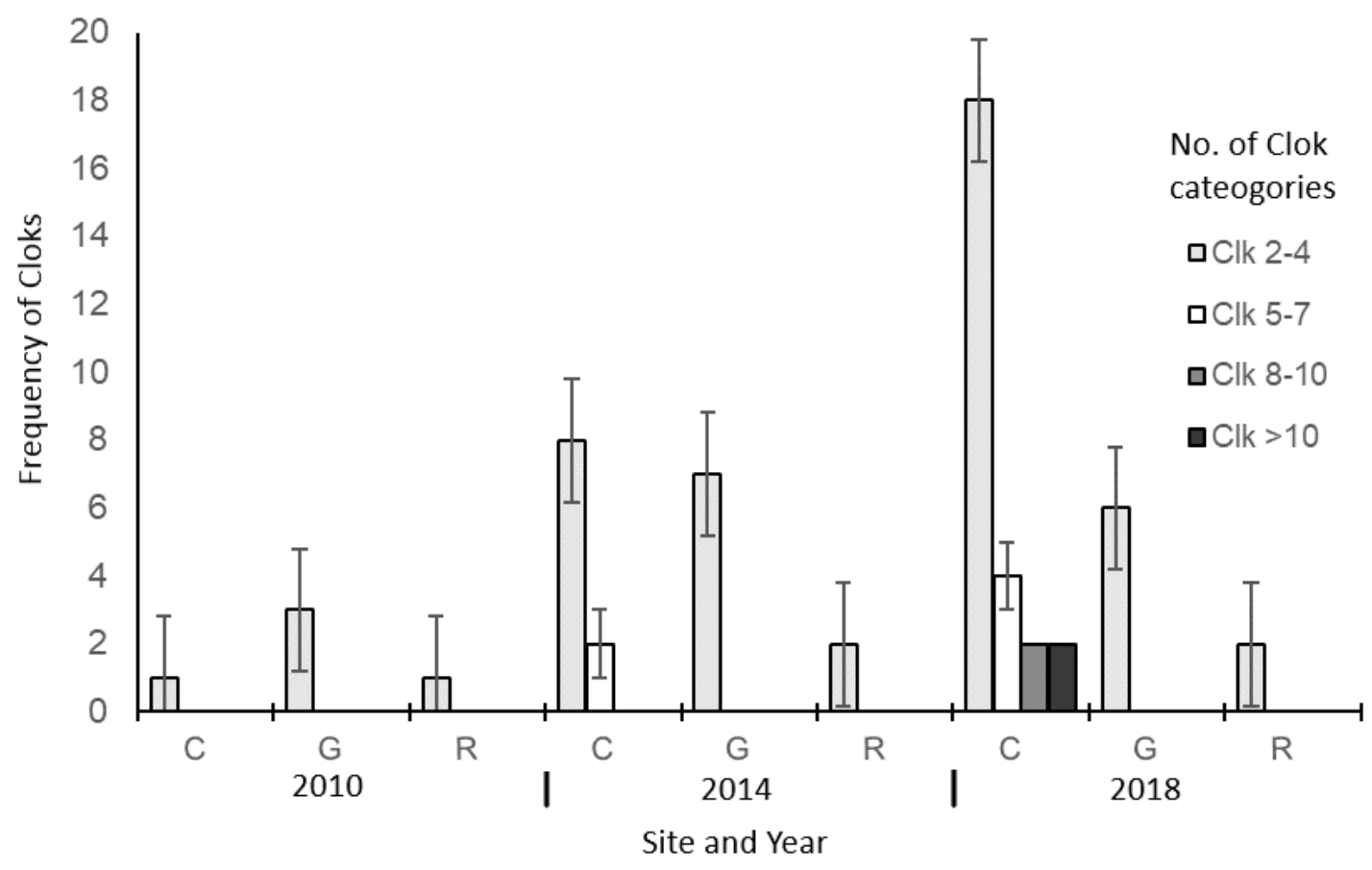

154 Figure 2. Frequency of each Clok (classified by the number of live oysters attached together in a

155 single matrix) for the categories $2-4,5-7,8-10$ and $>10$ oysters per Clok for Cunningburn (C),

156 Greyabbey (G) and Ringhaddy (R) sites in 2010, 2014 and 2018. Means \pm SD $(n=3)$.

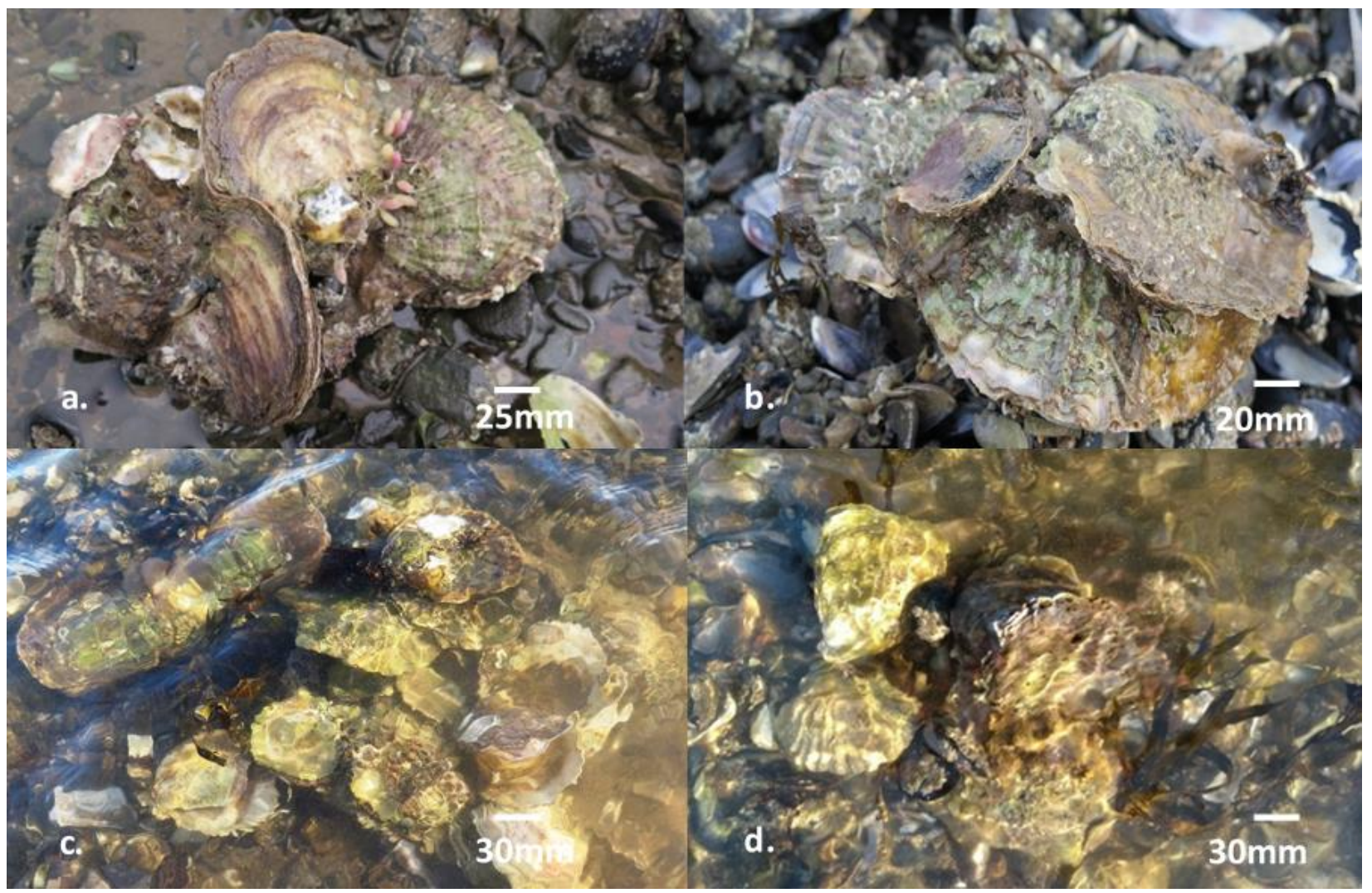

158 Figure 3. Digital images (a-d) from Cunningburn site (2018) showing multiple Ostrea edulis Cloks on

159 a Mytilus edulis dominant mixed shell substrate. 
161 ranged from $1-13 \mathrm{~cm}$ (Fig. 4). The average estimated age of the Clok assemblages ranged from 3.3 - 9.7 years.
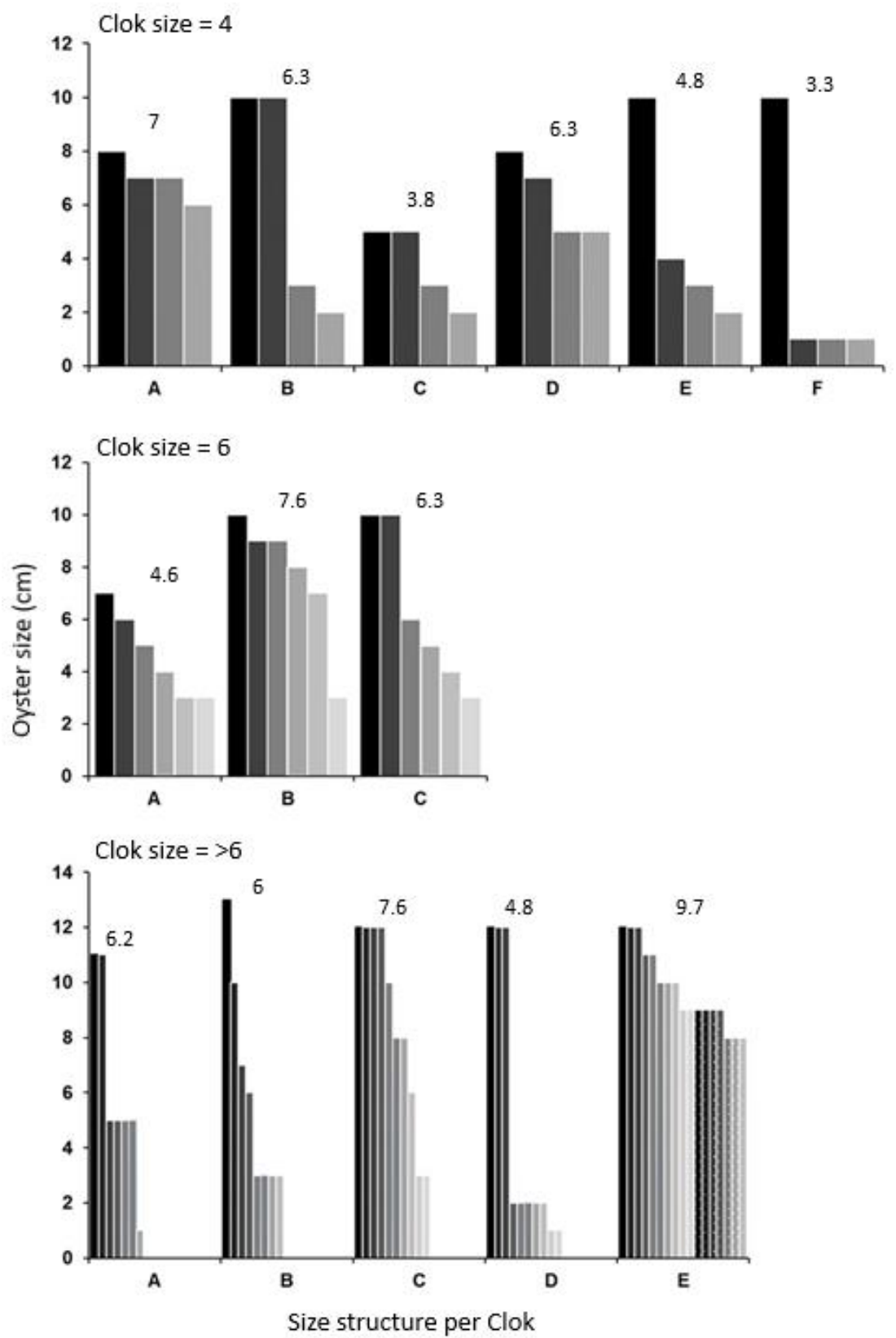

164 Figure 4. Size of Ostrea edulis individuals within conjoined / Clok assemblages of $>4$ oysters at 165 Cunningburn 2018. Numbers denote the average age of Clok/multiple attachment assemblage 166 based on Richardson et al. (1993) and letters denote every individual Clok. 


\section{Discussion}

The European native oyster has been regarded as a bed forming bivalve with individuals creating assemblages rather than as interconnected bio-structural features (Korringa, 1946; Walne, 1964). Recent discoveries have identified extant mixed oyster reefs in the Netherlands and extinct subtidal O. edulis specific structures in Bulgaria (Micu and Todorova, 2007; Christianen et al., 2018). However, there has been no indications of intertidal $O$. edulis specific reef formations in the UK and Ireland, until now. The discovery of intertidal oyster settlements at Cunningburn clearly demonstrated that there is potential for 0 . edulis to form reef formations (Figs. 2-4).

Literature related to $O$. edulis when densities would have existed in numbers capable of forming 3D reef matrices pre-1700s, is almost absent from the archives. The few existing accounts use ambiguous terminologies and do not confirm if structural matrices were formed. The lack of clarity within the archives regarding $O$. edulis specific structures highlights the importance of this current discovery and those of Micu and Todorova (2007) and Christianen et al. (2018). The small intertidal multiple attachments discovered at Cunningburn are diminutive in comparison to the extinct Black Sea reefs (Micu and Todorova, 2007). However, the discovery within the current study confirms that $O$. edulis has the capability to form multiple attachments both in the intertidal as well as the subtidal. Further, the variation of size within the settled assemblages show that Clok formation was over numerous spawning events and not from a single spat-fall.

When casting doubt on the reef forming potential of $O$. edulis, the cementation and settlement biology of its larvae should not be ignored as it has been shown, on numerous occasions, that pediveligers favour the living shell edge of conspecifics (Korringa, 1941; Cranfield, 1973; RodriguezPerez et al., 2019). This behavior supports previous work conducted in Northern Ireland (Smyth et al. 2020). It is therefore quite plausible that in a situation when all the key settlement components are in place that multiple oyster attachments could result in 3D reef-like matrices. However, in Europe the current biological status of many $O$. edulis stocks would not permit the spawning 
intensity required for high density multiple attachments. Nonetheless, it would be flippant not to postulate that native oysters, during the epochs of their maximum densities, would not have created expansive structures like those discovered in the Black Sea. This is also supported by the numbers of oysters removed from heavily fished areas such as the Solent where $\sim 15$ million oysters were fished in 1978. The oysters must have been forming reefs as the square meterage of the suitable habitat would not allow for this number of oysters to be caught if there was not this kind of settlement (Jensen, 2000).

Furthermore, misinterpretations of the historical vocabulary used to describe 0 . edulis accumulations during periods of peak densities have probably added to the confusion surrounding the bioengineering capabilities of the native oyster. The Irish and English Fishery Commission reports of the 1800s referred to both "oyster beds and banks" (Went, 1962; Edwards, 1997). In the early 1800 s, oysters were said to lay as banks throughout the English Channel (Olsen, 1883). The North Sea fishermen of the era stated that "oysters lay in beds" (Metzger, 1873; Houziaux et al., 2008). Murie (1911) reports that in the 1870s fishermen from Essex, England were concerned about the dwindling oyster banks and reefs of the Blackwater and Korringa (1951) refers to the oyster banks of the Crouch.

An examination of the etymology of the words used to describe $O$. edulis accumulations gives some insight into the subtle differences in meanings. Usage of the word bank can be traced back to c. 1200 and finds its origin in both the Old Norse 'bank' and Old Danish 'banke' which refer to "a rising of ground in a sea" (Fowler, 1994). The word bed originated from a Middle High German interpretation of the Danish word 'bed' which meant "laying place or bottom of lake or sea" (Klein, 1971). Therefore, bank would suggest a raised topography formed by oysters whereas bed would be the place where the oysters were found. The word reef originating from the Old Norse 'rif' meaning "ridge in the sea" was not commonly used to describe the European oyster but was directed more towards below water rock formations which became visible at low water. However, 
a description of the benthos relating to the North Sea oyster grounds in the 1830 s describes them as; "being built of oysters, knitted and interlaced with countless other invertebrates with the bottom

221 hardened as a living crust" (Orton, 1937; Houziaux et al., 2008), a narrative that could be interpreted as a structured reef matrix. The lack of evidence confirming the native oyster as an active reef builder is not surprising when the intensity of the dredge fishery between the 1700 s and late-1800s is taken into consideration.

The current status of $O$. edulis populations and the conditioning of the associated scientific community to the prevalence of fragmented low stock assemblages has left many in the field, with good reason, to doubt if $O$. edulis was ever a species capable of structural conjoined settlements. However, the unique Cunningburn discovery at Strangford shows that if conditions are suitable, Ostrea edulis has the potential to bioengineer a 3D reef matrix within the intertidal. However, the debate as to whether attachments such as Cunningburn should be considered reefs or beds is premature as currently, most oyster assemblages do not exist in sufficient densities to allow for gregarious settlements of this nature. Nonetheless, the discoveries of this survey suggest the debate of reef or bed may not be too far-off and that potentially, 0 . edulis can form reefs.

Acknowledgements: The authors would like to thank the following funding bodies for making this work possible: EPSRC Engineering and Physical Sciences Research Council, the Marine Institute Ireland and the Department for the Economy Northern Ireland. 


\section{References}

Beck, M.W., Brumbaugh, R.D., Airoldi, L., Carranza, A., Coen, L.D., Crawford, C., Defeo, O., Edgar, G.J., Hancock, B., Kay, M.C. \& Lenihan, H.S. (2011). Oyster reefs at risk and recommendations for conservation, restoration, and management. Bioscience, 61(2),107-116.

Christianen, M. J. A., Lengkeek, W., Bergsma, J. H., Coolen, J. W. P., Didderen, K., Dorenbosch, M., Driessen, F.M., Kamermans, P., Reuchlin-Hugenholtz, E., Sas, H., \& Smaal, A. (2018). Return of the native facilitated by the invasive? Population composition, substrate preferences and epibenthic species richness of a recently discovered shellfish reef with native European flat oysters (Ostrea edulis) in the North Sea. Marine Biology Research, 14(6), 590-597.

Cranfield, H. J. (1973). Observations on the behaviour of the pediveliger of Ostrea edulis during attachment and cementing. Marine Biology, 22(3), 203-209.

Day, A. \& McWilliams, P. (1991). Ordnance Survey Memoirs of Ireland, Parishes of County Down II, 1832, 1834, 1837, North Down \& The Ards. Belfast: The Royal Irish Academy, 88-89.

Edwards, E. R. I. C. (1997). Molluscan fisheries in Britain. Noaa Technical report Nmfs, 129, 85-100.

Eyton, T. C. (1858). A History of the Oyster and the Oyster Fisheries. Voorst.

Fariñas-Franco, J. M., Pearce, B., Mair, J. M., Harries, D. B., MacPherson, R. C., Porter, J. S., Reimer, P.J \& Sanderson, W. G. (2018). Missing native oyster (Ostrea edulis L.) beds in a European Marine Protected Area: Should there be widespread restorative management? Biological Conservation, 221, 293-311.

Fowler, H. W. (1994). A dictionary of modern English usage. Wordsworth Editions.

Hammer, Ø., Harper, D. A., \& Ryan, P. D. (2001). PAST: Paleontological statistics software package for education and data analysis. Palaeontologia electronica, 4(1), 9.

Helmer, L., Farrell, P., Hendy, I., Harding, S., Robertson, M., \& Preston, J. (2019). Active management is required to turn the tide for depleted Ostrea edulis stocks from the effects of overfishing, disease and invasive species. PeerJ, 7, e6431. 
Houziaux, J. S., Kerckhof, F., Degrendele, K., Roche, M., \& Norro, A. (2008). The Hinder banks: yet an important region for the Belgian marine biodiversity. Brussels: Belgian Science Policy, 249.

Jensen, A. (2000). Fisheries of Southampton Water and the Solent, in: Collins, M. et al. (Ed.) Solent science: a review. Proceedings in Marine Science, 1: pp. 271-279

Johnson, M. P., Jessopp, M., Mulholland, O. R., McInerney, C., McAllen, R., Allcock, A. L., \& Crowe, T. P. (2008). What is the future for marine protected areas in Irish waters? In Biology and Environment: Proceedings of the Royal Irish Academy (pp. 9-15). Royal Irish Academy.

Kennedy, R. J., \& Roberts, D. (2006). Commercial oyster stocks as a potential source of larvae in the regeneration of Ostrea edulis in Strangford Lough, Northern Ireland. Journal of the Marine Biological Association of the United Kingdom, 86(1), 153-159.

Klein, E (1971). Comprehensive Etymological Dictionary of the English Language, Amsterdam: Elsevier Scientific Publishing Co.

Korringa, P. (1941) Experiments and observations on swarming, pelagic life and setting in the European Flat oyster, Ostrea edulis. Extract from the Archives Neerlandaises de Zoologie, 5, $1-249$

Korringa, P. (1946). A revival of natural oyster beds? Nature, 158, 586-587.

Korringa, P. (1951). The shell of Ostrea edulis as a habitat. Government Institute for Fishery Investigations, Bergen op Zoom, Holland, Vol.10, 32-152.

Kregting, L., \& Elsäßer, B. (2014). A hydrodynamic modelling framework for Strangford Lough part 1: tidal model. Journal of Marine Science and Engineering, 2(1), 46-65.

Laing, I., Walker, P., \& Areal, F. (2006). Return of the native-is European oyster (Ostrea edulis) stock restoration in the UK feasible? Aquatic Living Resources, 19(3), 283-287.

Lewis, S. (1837). A Topographical Dictionary of Ireland. London: S. Lewis. 
Lipcius, R. N., Burke, R. P., McCulloch, D. N., Schreiber, S. J., Schulte, D. M., Seitz, R. D., \& Shen, J. (2015). Overcoming restoration paradigms: value of the historical record and metapopulation dynamics in native oyster restoration. Frontiers in Marine Science, 2, 65.

MCCIP (2017). Marine Climate Change Impacts: 10 years' experience of science to policy reporting. (Eds. Frost M, Baxter J, Buckley P, Dye S and Stoker B) Summary Report, MCCIP, Lowestoft, 12pp. doi:10.14465/2017.arc10.000-arc

Metzger, A. (1873). Faunistische Ergebnisse der im Sommer 1871 unternommenen Exkursionen. Jahresbericht der Commission zur Untersuchung der deutschen Meere, Kiel, 1, 169.

Micu, D., \& Todorova, V. (2007). Biodiversity of the Western Black Sea. Marine Biodiversity and Ecosystem Functioning, MarBEF Newsletter, 7, 26-29.

Mieszkowska, N., Firth, L., \& Bentley, M. (2013). Impacts of climate change on intertidal habitats. MCCIP Science Review, 2013, 180-192.

Murie, J. (1911). Slipper Limpet" or "Boat Shell" (Crepidula fornicata): its introduction and influence on Kent and Essex Oyster Beds. Zoologist, 15, 401-415.

Olsen, O. T. (1883). The Piscatorial Atlas of the North Sea, English and St. George's Channels: Illustrating the Fishing Ports, Boats, Gear, Species of Fish (how, where and when Caught), and Other Information Concerning Fish and Fisheries.

Orton, J. H. (1937). Oyster Biology and Oyster-culture: Being the Buckland Lectures for 1935. E. Arnold \& Company.

Pogoda, B., Brown, J., Hancock, B., Preston, J., Pouvreau, S., Kamermans, P., Sanderson, W., \& von Nordheim, H. (2019). The Native Oyster Restoration Alliance (NORA) and the Berlin Oyster Recommendation: bringing back a key ecosystem engineer by developing and supporting best practice in Europe. Aquatic Living Resources, 32, 13. 
Richardson, C.A., Collis, S.A., Ekaratne, K., Dare, P. and Key, D., 1993. The age determination and growth rate of the European flat oyster, Ostrea edulis, in British waters determined from acetate peels of umbo growth lines. ICES Journal of Marine Science, 50(4), pp.493-500.

Roberts, D. Allcock, L. Fariñas-Franco, J.M. Gorman, E. Maggs, C.A. Mahon, A.M. Smyth, D. Strain, E. Wilson, C.D. (2011). Modiolus Restoration Research Project: Final Report and Recommendations. Report prepared for Northern Ireland Environmental Agency.

Rodriguez-Perez, A., James, M., Donnan, D. W., Henry, T. B., Møller, L. F., \& Sanderson, W. G. (2019). Conservation and restoration of a keystone species: Understanding the settlement preferences of the European oyster (Ostrea edulis). Marine pollution bulletin, 138, 312-321.

Smyth, D., Roberts, D., \& Browne, L. (2009). Impacts of unregulated harvesting on a recovering stock of native oysters (Ostrea edulis). Marine Pollution Bulletin, 58(6), 916-922.

Smyth, D., Kregting, L., Elsäßer, B., Kennedy, R., \& Roberts, D. (2016). Using particle dispersal models to assist in the conservation and recovery of the overexploited native oyster (Ostrea edulis) in an enclosed sea lough. Journal of sea research, 108, 50-59.

Smyth D, Mahon A.M, Roberts D, Kregting L (2018). Settlement of Ostrea edulis is determined by the availability of hard substrata rather than its nature: implications for stock recovery and restoration of the European oyster. Aquatic Conservation Marine and Freshwater Ecosystems. https://doi.org/10.1002/aqc.2876

Smyth, D. M., Horne, N. S., Ronayne, E., Millar, R. V., Joyce, P. W., Hayden-Hughes, M., \& Kregting, L. (2020). Wild gregarious settlements of Ostrea edulis in a semi-enclosed Sea Lough; a case study for unassisted restoration. Restoration Ecology. doi:10.1111/rec.13124

Todorova, V., Micu, D., \& Klisurov, L. (2009). Unique oyster reefs discovered in the Bulgarian Black Sea. Comptes rendus de l'Académie bulgare des Sciences, 62(7), 871-874.

Walne, P. R. (1964). Observations on the fertility of the oyster (Ostrea edulis). Journal of the Marine Biological Association of the United Kingdom, 44(2), 293-310. 
341 Went, A. E. (1962). Historical notes on the oyster fisheries of Ireland. Proceedings of the Royal Irish Academy. Section C: Archaeology, Celtic Studies, History, Linguistics, Literature, 62, 195-223.

343 Yonge, C.M. (1966). Oysters, $2^{\text {nd }}$ edition. Collins, London.

344 https://nativeoysternetwork.org/ Native Oyster Restoration Network for UK and Ireland 